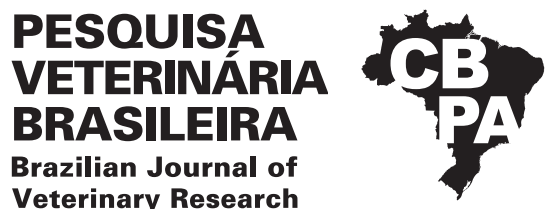

Pesq. Vet. Bras. 41:e06129, 2021

DOI: 10.1590/1678-5150-PVB-6129

Original Article

Livestock Diseases

ISSN 0100-736X (Print)

ISSN 1678-5150 (Online)

\title{
Proteomics characterization of Staphylococcus spp. from goat mastitis and phenogeno-typical assessment of resistance to beta-lactamics ${ }^{1}$
}

\author{
Camila S. Pereira ${ }^{2}$, Lídia M.M. Santos ${ }^{2}$, Leandro S. Machado ${ }^{2 *}$ (D), \\ Dayanne A. Melo ${ }^{3}$ (D), Shana M.O. Coelho ${ }^{3}$, Virginia L.A. Pereira ${ }^{2}$, \\ Miliane M.S. Souza ${ }^{3}$ and Elmiro R. Nascimento ${ }^{2}$
}

\begin{abstract}
Pereira C.S., Santos L.M.M., Machado L.S., Melo D.A., Coelho S.M.O., Pereira V.L.A., Souza M.M.S. \& Nascimento E.R. 2021. Proteomics characterization of Staphylococcus spp. from goat mastitis and phenogeno-typical assessment of resistance to beta-lactamics. Pesquisa Veterinária Brasileira 41:e06129, 2021. Departamento de Medicina Veterinária Preventiva e Saúde Pública, Faculdade de Veterinária, Universidade Federal Fluminense, Rua Dr. Vital Brazil Filho 64, Vital Brazil, Niterói, RJ 24230-340, Brazil. E-mail: leomachadovet@gmail.com

Mastitis occupies a prominent place among the diseases that affect dairy herds due to economic problems and public health. Staphylococcus spp. are infectious agents more involved in the etiology of caprine mastites, especially coagulase-negative Staphylococcus. Nineteen isolates of Staphylococcus spp. were obtained from subclinical caprine mastitis. All isolates were characterized by MALDI-TOF MS, being 47.36\% (9/19) identified for S. epidermidis, $15.78 \%(3 / 19)$ for S. warneri, $10.52 \%(2 / 19)$ for S. aureus and S. caprae and $5.26 \%(1 / 19)$ for $S$. lugdunensis, S. simulans, and S. cohnii. All isolates characterized by MALDI-TOF were subjected a to polymerase chain reaction (PCR) for the 16S rRNA gene of Staphylococcus spp. to confirm the gender. After determining the species, tests for phenotypic detection of resistance to beta-lactams were carried out simple disk diffusion oxacillin, cefoxitin, penicillin G and amoxicillin + clavulanic acid, agar "screen" oxacillin and microdilution (MIC) cefoxitin. The disk diffusion test showed a strength of $58 \%(11 / 19)$ for penicillin G, 26.31\% (5/19) for cefoxitin and $26.31 \%$ (5/19) for oxacillin. All strains were susceptible to amoxicillin + clavulanic acid and agar "screen" oxacillin. In the MIC, 63.15\% (12/19) of the samples were cefoxitin resistant (MIC $>4.0 \mu \mathrm{g} / \mathrm{ml}$ ). Then isolates were subjected to detection of the $m e c \mathrm{~A}$ resistance genes and regulators (mecl and $m e c \mathrm{RI}$ ), mecC and blaZ. Two samples of Staphylococcus epidermidis had the mecA gene. All isolates were negative for the mecA gene variant, mecl, mecRI, mecC and blaZ. These findings reinforce the importance of this group of microorganisms in the etiology of subclinical mastitis in goats and open perspectives for future research to investigate the epidemiology of the disease.
\end{abstract}

INDEX TERMS: Proteomics, Staphylococcus spp., goat, mastitis, resistance, beta-lactamics.

RESUMO.- [Caracterização proteômica de Staphylococcus spp. oriundos de mastite caprina e avaliação fenogenotípica da resistência aos beta-lactâmicos.] A mastite ocupa lugar

\footnotetext{
${ }^{1}$ Received on October 8, 2020.

Accepted for publication on December 29, 2020.

${ }^{2}$ Departamento de Saúde Coletiva Veterinária e Saúde Pública, Faculdade de Veterinária, Universidade Federal Fluminense (UFF), Rua Dr. Vital Brazil Filho 64, Vital Brazil, Niterói, RJ 24230-340, Brazil. *Corresponding author: leomachadovet@gmail.com

${ }^{3}$ Departamento de Microbiologia Veterinária, Universidade Federal Rural do Rio de Janeiro (UFRRJ), Campus Universitário, Rodovia BR-465 Km 7, Seropédica, RJ 23851-970, Brazil.
}

de destaque entre as doenças que acometem o rebanho leiteiro, em virtude de problemas econômicos e de saúde pública. Staphylococcus spp. são os agentes infecciosos mais envolvidos na etiologia das mastites caprinas, principalmente Staphylococcus coagulase negativo. Dezenove isolados de Staphylococcus spp. foram obtidos a partir de mastite caprina subclínica. Todos os isolados foram caracterizados por MALDI-TOF MS, sendo 47,36\% (9/19) identificadas como S. epidermidis, $15,78 \%(3 / 19)$ como $S$. warneri, $10,52 \%$ $(2 / 19)$ como $S$. caprae e $S$. aureus e $5,26 \%(1 / 19)$ tanto para $S$. lugdunensis, como para $S$. simulans e $S$. cohnii. Todos os isolados caracterizados pelo MALDI-TOF foram submetidos 
a reação em cadeia da polimerase (PCR) para o gene 16rRNA de Staphylococcus spp. para a confirmação do gênero. Após a determinação da espécie, foram realizadas as provas para a detecção fenotípica de resistência aos beta-lactâmicos: difusão em disco simples de oxacilina, cefoxitina, penicilina G e amoxacilina +ácido clavulânico, ágar "screen" de oxacilina e microdiluição em caldo (MIC) de cefoxitina. 0 teste de difusão em disco demonstrou resistência de 58\% (11/19) para penicilina G, $26,31 \%$ (5/19) para cefoxitina e $26,31 \%$ (5/19) para oxacilina. Todas as amostras foram sensíveis a amoxicilina + ácido clavulânico e ao ágar "screen" de oxacilina. Pelo MIC, 63,15\% (12/19) das amostras foram resistentes a cefoxitina (MIC $>4,0 \mu \mathrm{g} / \mathrm{ml}$ ). Em seguida os isolados foram submetidos a detecção dos genes de resistência mecA e seus reguladores (mecl e $m e c \mathrm{RI}$ ), $m e c \mathrm{C}$ e blaZ. Duas amostras de $S$. epidermidis apresentaram o gene mecA. Todos os isolados foram negativos para a variante do gene mecA, mecl, mecRI, $m e c \mathrm{C}$ e blaz. Tais achados reforçam a importância deste grupo de microrganismos na etiologia da mastite subclínica em caprinos e abre perspectivas para futuras pesquisas para a investigação da epidemiologia da doença.

TERMOS DE INDEXAÇÃO: Proteômica, Staphylococcus spp., mastite, caprinos, resistência a beta-lactâmicos.

\section{INTRODUCTION}

Mastitis, the inflammatory process of the mammary gland, is considered to be one of the major diseases affecting herds of dairy goats. This disease is associated with losses in production and economic losses to the farmer and industry (Almeida et al. 2013). Bacteria of the genus Staphylococcus spp. are among the main etiological agents of caprine mastitis and are frequently resistant to antimicrobials, especially beta-lactams, thus limiting the choice of antibiotic for the treatment of infections caused by this agent (Garino Junior et al. 2011, Almeida et al. 2013, Gomes \& Henriques 2016).

Recent changes in the taxonomy of some species of the genus Staphylococcus have made species differentiation more difficult, especially in Veterinary Medicine. Thus, the use of molecular markers associated with the phenotypic diagnosis allows a more reliable and precise characterization (Motta et al. 2014).

The proteomic analysis by MALDI-TOF mass spectrometry has gained prominence due to advantages such as cost-benefit, fast and accurate results (Bannoehr \& Guardabassi 2012), allowing the identification of different microorganisms at the species level, with a minimum sample amount, low cost, insignificant levels of chemical and biological waste generated and time to obtain extraordinarily short results (Cherkaoui et al. 2010, Alatoom et al. 2011, Carbonnelle et al. 2011).

Staphylococcal resistance to beta-lactam antibiotics is primarily due to two mechanisms: the production of extracellular beta-lactamase enzyme encoded by the blaZ gene and the production of PBP2a or PBP2; a low-affinity penicillin-binding protein encoded by mecA gene. The blaZ gene is usually located in plasmids and may also be chromosomal (Kuroda et al. 2001, Lowy 2003). The mecA gene is inserted into a mobile genetic element called Staphylococcal cassette chromosome mec (SCCmec), composed of several essential genetic elements: the mec complex, composed of the pathogenic island IS431, the mecA genes and their mecI and mecR1 regulators, and the complex ccr (Chromosome Recombinases Cassette), characterized by the presence of genes encoding recombinase (Weller 2000, Ma et al. 2002).

There are few studies conducted to investigate the profile of sensitivity and verification of resistance genes to betalactam antibiotics in Staphylococcus spp. isolated from caprine mastitis. Thus, this work aimed to characterize isolates using the MALDI-TOF technique and to identify the phenogenotypic profile of beta-lactam resistance in Staphylococcus spp.

\section{MATERIALS AND METHODS}

A total of 140 goat milk samples were collected from different cities of Rio de Janeiro, among them Seropédica, Niterói, Friburgo, Teresópolis, Paraíba do Sul, São Gonçalo, Engenheiro Paulo de Frontin, Tanguá and Valença. From these 140 samples, 19 isolates of Staphylococcus spp. were obtained from subclinical caprine mastites. These materials were stored in Brain Heart Infusion (BHI) broth with $10 \%$ glycerol at $-80^{\circ} \mathrm{C}$. The respective article obtained the number 593 from the Ethics Commission on Animal Use of the "Universidade Federal Fluminense" (UFF).

Identification by MALDI-TOF MS (Seng et al. 2010). The isolates were evaluated by the Matrix-Assisted Laser Ionization/ Desorption Flight Time (MALDI-TOF) technique. For the preparation of the samples, the isolates were cultured on BHI agar at $37^{\circ} \mathrm{C}$ for 24 hours. Each bacterial culture was transferred to the microplate ( 96 MSP, Bruker-Billerica, USA) and the bacterial pellet; sufficient lysis solution (70\% formic acid, Sigma-Aldrich) was added to cover it. Then $1 \mu \mathrm{l}$ of matrix solution (alpha-cyano-4-hydroxy cinnamic acid diluted in 50\% acetonitrile, and 2.5\% trifluoroacetic acid, SigmaAldrich $^{\circledR}$ ) was used to cover the bacterial extract, which was ready to be processed. The spectra of each sample were generated in a mass spectrometer (MALDI-TOF LT MicroflexBruker, Bruker ${ }^{\circledR}$ ) equipped with a $337 \mathrm{~nm}$ nitrogen laser in the linear mode controlled by the FlexControl 3.3 program $\left(\right.$ Bruker $\left.^{\circledR}\right)$. The spectra were collected in the mass range between 2,000-20,000m/s and later analyzed by the MALDI Biotyper 2.0 program $\left(\right.$ Bruker $^{\circledR}$ ), with standardized configurations for bacterial identification. The results ranged from zero to three, and the higher the value, the more reliable the identification. In this study, those that presented values equal to or greater than two were considered as an acceptable identification.

Extraction of total bacterial DNA (Gregory et al. 2009). The 19 isolates studied were replicated in BHI agar (HIMEDIA) and submitted to DNA extraction for genotypic analyses. To extract the total DNA, each isolate was grown in $5 \mathrm{ml}$ of BHI broth at $37^{\circ} \mathrm{C}$ for $12-16$ hours at $150 \mathrm{rpm}$. Then $1.5 \mathrm{ml}$ of the culture was transferred to $1.5 \mathrm{ml}$ microtubes and centrifuged for 5 minutes at $1239 \mathrm{~g}$, and the supernatant was discarded, with three replicates. Cells were resuspended in $600 \mu \mathrm{l}$ of extraction solution $(200 \mathrm{mM}$ Tris- $\mathrm{HCl} \mathrm{pH}$ 8.0, 25mM EDTA pH 8.0, $1 \%$ SDS, $25 \mathrm{mM} \mathrm{NaCl}$ ) and vortexed, followed by incubation at $65^{\circ} \mathrm{C}$ for 30 minutes. After the stipulated time, the tubes were cooled to room temperature and $600 \mu \mathrm{l}$ of phenol: chloroform: isoamyl alcohol [1-1 (24: 1)] was added, followed by homogenization for 2 minutes and centrifugation at $145 \mathrm{rpm}$ for 10 minutes. The upper phase was transferred to a new microtube (approximately $400 \mu \mathrm{L}$ ), and 2 volumes of $100 \%$ ice-cold ethanol (PROQUIMIOS) was added, followed by incubation at $20^{\circ} \mathrm{C}$ for 2 or 12 hours for precipitation of the DNA. Subsequently, the microtubes were centrifuged at $14549 \mathrm{~g}$ for 30 minutes, the supernatant was discarded, and the pellet washed with $70 \%$ ethanol (approximately $500 \mu \mathrm{L})$. After drying at room temperature in an exhaust hood, the pellets were resuspended in $30 \mu \mathrm{l}$ of ultra-pure water (QUATRO G) 
and stored at $-20^{\circ} \mathrm{C}$. The DNA concentration estimation was done by comparison with the band intensity standard of the Lambda marker $(\lambda)$ (Promega ${ }^{\circledR}$ ) at concentrations of 25 and 50ng. Quality was determined by the absence of traces along the gel.

Polymerase Chain Reaction (PCR). The concentrations used in all PCR reactions were $1 \mathrm{X}$ Buffer $(10 \mathrm{mM}$ Tris- $\mathrm{HCl}, 50 \mathrm{mM} \mathrm{KCl}$, and $0.1 \%$ Triton $\mathrm{X}-100,2.0 \mathrm{mM} \mathrm{MgCl} 2, \mathrm{pH} 9.0$ ), $0.3 \mu \mathrm{M}$ of each primer, $0.2 \mathrm{mM}$ dNTP (FERMENTAS), $1 \mathrm{U}$ of Dream Taq $^{\mathrm{TM}}$ Green DNA Polymerase (FERMENTAS) and milli-Q water to complete a total reaction volume of $20 \mu \mathrm{L}$ and about $20 \mathrm{ng}$ of total DNA. The fragments were evaluated by $1.5 \%$ agarose gel electrophoresis, containing SYBR Green dye (INVITROGEN) and visualized by the L-PIX EX (LoccusBiotechnology) image capture system. The genotypic characterization was performed by amplification using specific primers for the genus Staphylococcus (Zhang et al. 2004, Jaffe et al. 2000) (Table 1). The samples were applied with $1 \mu \mathrm{L}$ of SYBR Green (INVITROGEN) and diluted in the $0.8 \%$ agarose gel and submitted to electrophoresis. The gel was then developed with SYBR Green (INVITROGEN) by the L-PIX EX (LoccusBiotechnology) image capture system.

Phenotypic detection of beta-lactam antimicrobial resistance. Resistance phenotype detection tests were performed according to the standards established by the Clinical Laboratory Standard Institute (CLSI 2018). Disc diffusion technique was performed with Cefoxitin $(30 \mu \mathrm{g})$, Oxacillin $(1 \mu \mathrm{g})$, Penicillin G (10UI) and Amoxicillin

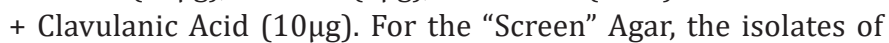
Staphylococcus spp. were seeded in culture medium with a final concentration of $6 \mu \mathrm{g} / \mathrm{mL}$ oxacillin, and after 24 hours incubation at $37^{\circ} \mathrm{C}$, any grown colony was considered resistant (CLSI 2018). Broth microdilution method (MIC) with antimicrobial cefoxitin was used to determine oxacillin resistance mediated by the mecA gene (CLSI 2018).

Detection of oxacillin resistance genes from Staphylococcus spp. PCR was performed to amplify the genes: mecA (Murakami et al. 1991), mecA variant (Melo et al. 2014), mecI (Oliveira \& Lencastre 2002), mecRI and blaZ (Rosato et al. 2003) (Table 2).

\section{RESULTS AND DISCUSSION}

The MALDI-TOF technique identified $47.36 \%$ (9/19) as Staphylococcus epidermidis, $15.78 \%$ (3/19) as Staphylococcus warneri, $10.52 \%(2 / 19)$ as Staphylococcus caprae and Staphylococcus aureus and 5,26\% (1/19) as Staphylococcus lugdunensis, Staphylococcus simulans and Staphylococcus scohnii. This result corroborates with several studies on the etiology of caprine mastitis in Brazil that point to coagulasenegative Staphylococcus as the most frequent microorganisms (Langoni et al. 2006, Peixoto et al. 2010, Almeida et al. 2013, Cavalcante et al. 2013, Martins et al. 2017, Lima et al. 2018). Besides, all 19 samples were submitted to $16 \mathrm{~S}$ rRNA gene PCR for confirmation of the species Staphylococcus spp.

The phenotypic resistance to oxacillin is extremely variable and dependent on mecA gene expression. This variability is recognized as phenotypic heteroresistance and is characterized by the fact that all heterogeneously resistant bacterial populations carry the mecA gene, the genotype marker of resistance, but not all phenotypically express their resistance in the same way (Cauwelier et al. 2004).

Two isolates of $S$. epidermidis were positive for the mecA gene as proposed by Murakami et al. (1991) (Table 1) similar to a study by Martins et al. (2017) and Coimbra-e-Souza et al. (2019). All the isolates studied were negative for the mecA gene as proposed by Melo et al. (2014), who characterized a variant of the mecA gene in bovine mastitis isolates. No positive isolates were found for the mecl and mecRI regulators, homologous to the mecA, mecC gene and the blaZ gene.

During some studies with isolates of Staphylococcus spp. from subclinical caprine mastitis in Brazil by França et al. (2012) and Peixoto et al. (2013), oxacillin resistance of $15.8 \%$ and $54.5 \%$, respectively; were observed in the disc diffusion test, but in none of them was it positive for the gene. However, $40.2 \%$ and $33.3 \%$, respectively; of the same isolates contained the gene blaz. For MIC, $63.15 \%(12 / 19)$ of

Table 1. Primers used for identification of Staphylococcus spp.

\begin{tabular}{cccc}
\hline Gene/Fragment size & Sequence of primers $\left(5^{\prime}-3^{\prime}\right)$ & Reference & Cycle* \\
\hline $16 \mathrm{~S} r R N A /(756 \mathrm{pb})$ & AAC TCT GTT ATT AGG GAA GAA CA & Zhang et al. (2004) & $\left(94^{\circ} \mathrm{C} 40 \mathrm{~s}, 64^{\circ} \mathrm{C} 1 \mathrm{~min}, 72^{\circ} \mathrm{C} 1 \mathrm{~min} 12 \mathrm{~s}\right) \times 30$ \\
& CCA CCT TCC TCC GGT TTG TCA CC & Jaffe et al. (2000) &
\end{tabular}

Table 2. Primers used for amplification of resistance genes

\begin{tabular}{|c|c|c|}
\hline Gene/Fragment size & Sequence of primers $\left(5^{\prime}-3^{\prime}\right)$ & Cycle* $^{*}$ \\
\hline mecA (Murakami) & AAA ATC GAT GGT AAA GGT TGG C & $\left(94^{\circ} \mathrm{C} 1 \mathrm{~min}, 55^{\circ} \mathrm{C} 1 \mathrm{~min}, 72^{\circ} \mathrm{C} 1 \mathrm{~min}\right) \times 30$ and $72^{\circ} \mathrm{C} 10 \mathrm{~min}$ \\
\hline$(533 \mathrm{pb})$ & AGT TCT GCA GTA CCG GAT TTG C & \\
\hline mecA (Melo) & CAG GCA TGC AGA AAA ATC AA & $95^{\circ} \mathrm{C} 5 \min \left(94^{\circ} \mathrm{C} 1 \mathrm{~min}, 50^{\circ} \mathrm{C} 1 \mathrm{~min}, 72^{\circ} \mathrm{C} 1 \mathrm{~min}\right) \times 30$ and $72^{\circ} \mathrm{C} 10 \mathrm{~min}$ \\
\hline$(809 \mathrm{pb})$ & TTG AGT CGA ACC AGG TGA TG & \\
\hline mecI & ATC AAG ACT TGC ATT CAG GC & $94^{\circ} \mathrm{C} 4 \mathrm{~min}\left(94^{\circ} \mathrm{C} 30 \mathrm{~s}, 53^{\circ} \mathrm{C} 30 \mathrm{~s}, 72^{\circ} \mathrm{C} 1 \mathrm{~min}\right) \times 30$ and $72^{\circ} \mathrm{C}-4 \mathrm{~min}$ \\
\hline$(209 \mathrm{pb})$ & GCG GTT TCA ATT CAC TTG TC & \\
\hline mecC & GAA AAA AAG GCT TAG AAC GCC TC & $94^{\circ} \mathrm{C} 15 \mathrm{~min}\left(94^{\circ} \mathrm{C} 30 \mathrm{~s}, 59^{\circ} \mathrm{C} 1 \mathrm{~min}, 72^{\circ} \mathrm{C} 1 \mathrm{~min}\right) \times 30$ and $72^{\circ} \mathrm{C} 10 \mathrm{~min}$ \\
\hline$(138 \mathrm{pb})$ & GAA GAT CTT TTC CGT TTT CAG C & \\
\hline mecC & GAA AAA AAG GCT TAG AAC GCC TC & $94^{\circ} \mathrm{C} 15 \mathrm{~min}\left(94^{\circ} \mathrm{C} 30 \mathrm{~s}, 50^{\circ} \mathrm{C} 1 \mathrm{~min}, 72^{\circ} \mathrm{C} 1 \mathrm{~min}\right) \times 35$ and $72^{\circ} \mathrm{C} 10 \mathrm{~min}$ \\
\hline$(718 \mathrm{pb})$ & CCT GAA TC[W] GCT AAT AAT ATT TC & \\
\hline blaZ & TAC AAC TGT AAT ATC GGA GG & $94^{\circ} \mathrm{C} 5 \min \left(94^{\circ} \mathrm{C} 30 \mathrm{~s}, 58^{\circ} \mathrm{C} 30 \mathrm{~s}, 72^{\circ} \mathrm{C} 30 \mathrm{~s}\right) \times 35$ and $72^{\circ} \mathrm{C} 5 \mathrm{~min}$ \\
\hline
\end{tabular}

Pesq. Vet. Bras. 41:e06129, 2021 
the samples were resistant to cefoxitin, with $52.63 \%$ (10/19) with MIC $>8.0 \mu \mathrm{g} / \mathrm{ml}$ and $10.52 \%(2 / 19)$ with $\mathrm{MIC}>16 \mu \mathrm{g} / \mathrm{ml}$ (Table 3). For MIC, the same isolate of $S$. epidermidis showed resistance to cefoxitin, and also produced resistance to oxacillin and penicillin $\mathrm{G}$ in the disk diffusion test, in addition to the positivity for the $m e c A$ gene. However, in the remaining isolates that showed resistance in this test, the mecA gene was not detected. This fact can be justified by the loss of the gene and the use of another form of resistance. This study corroborates with the work of Martins et al. (2017) and Lima et al. (2018) who reported a resistance profile to penicillin and oxacillin, antimicrobials of the beta-lactam class.

Van Griethuysen et al. (2005) conducted a study that demonstrated the loss of the mecA gene in isolates kept under freezing. In this study, the isolates were maintained in this condition until molecular analysis. This result indicates that, despite its high specificity, and the fact that the technique for molecular genotype characterization is considered definitive to prove the presence of the gene, the sensitivity of the gene may vary with the conservation of the samples.

The identification of the mecA gene in two isolates of Staphylococcus spp reinforces its epidemiological importance and significance in caprine mastitis. These strains tend to impair treatment, even when they are secondary etiological agents, increasing the tendency to chronification of the disease and possibilities of dissemination among animals. The carriage of antimicrobial resistance genes by these microorganisms in a dairy environment is already a potential risk to animal health and public health, due to interspecific genetic transfer, including $S$. aureus, and direct transmission of resistant pathogens to humans.

Other classes of PBPs (e.g., PBP3 and PBP4) may be related to beta-lactam resistance. Memmi et al. (2008) reported that PBP4 is the key element for beta-lactam resistance in community-acquired methicillin-resistant $S$. aureus strains (CA-MRSA), and that PBP2a, the mecA gene product, is not a determinant of resistance to oxacillin.

The high rate of phenotypic resistance and the low genotypic detection in Staphylococcus spp. isolates may be related to changes in genes triggered by mutations, phages, plasmids and transposons. Thus, the multiplicity of factors associated with beta-lactam resistance requires careful investigation. The detection of different genetic markers for resistance, as well as the study of the regulation of the gene expression of the mec system, allows to deepen the understanding of the real value of its detection in the prediction of the resistance to antimicrobial beta-lactams, as recommended by CLSI.

\section{CONCLUSION}

The study detected Staphylococcus spp. as a causative agent of subclinical mastitis in goats. Among Staphylococcus coagulase negative, the highest frequency found was for S. epidermidis and among Staphylococcus coagulase positive, $S$. aureus was confirmed as a prevalent species. Isolates of Staphylococcus spp. showed high resistance to penicillin, being the beta-lactam and beta-lactamase inhibitor the most effective antibiotic.

Table 3. Phenogenotypic profile of beta-lactam resistance in Staphylococcus spp. isolates identified by MALDI-TOF and confirmed by PCR in isolates of goat's milk with mastitis

\begin{tabular}{|c|c|c|c|c|c|c|}
\hline Identification by MALDI-TOF & CFO & OXA & PEN & AMC & MIC CFO $(\mu \mathrm{g} / \mathrm{ml})$ & mecA (Murakami) \\
\hline S. epidermidis & $S$ & $S$ & $\mathrm{R}$ & $S$ & $S$ & - \\
\hline S. warneri & S & S & S & S & $\mathrm{R}=8.0$ & - \\
\hline S. lugdunensis & S & S & S & $S$ & $\mathrm{R}=8.0$ & - \\
\hline S. epidermidis & $S$ & $S$ & $\mathrm{R}$ & $S$ & $S$ & - \\
\hline S. epidermidis & S & $S$ & $\mathrm{R}$ & $S$ & $S$ & - \\
\hline S. epidermidis & $S$ & $\mathrm{R}$ & $\mathrm{R}$ & $S$ & $S$ & - \\
\hline S. epidermidis & $\mathrm{R}$ & $\mathrm{R}$ & $\mathrm{R}$ & $S$ & $\mathrm{R}=8.0$ & - \\
\hline S. epidermidis & $S$ & $S$ & $\mathrm{R}$ & $S$ & $\mathrm{R}=8.0$ & - \\
\hline S. warneri & $\mathrm{R}$ & $\mathrm{R}$ & $S$ & $S$ & $R=8.0$ & - \\
\hline S. epidermidis & S & S & $\mathrm{R}$ & S & S & - \\
\hline S. warneri & $\mathrm{S}$ & S & S & $S$ & $R=8.0$ & - \\
\hline S. simulans & $S$ & $S$ & S & $S$ & $\mathrm{R}=8.0$ & - \\
\hline S. epidermidis & S & $\mathrm{R}$ & $\mathrm{R}$ & $S$ & $R=8.0$ & + \\
\hline S. caprae & $\mathrm{S}$ & S & S & S & S & - \\
\hline S. caprae & S & S & S & $S$ & $S$ & - \\
\hline S. cohnii & $\mathrm{R}$ & S & $\mathrm{R}$ & S & $R=16.0$ & - \\
\hline S. epidermidis & S & S & $\mathrm{R}$ & S & $\mathrm{R}=16.0$ & + \\
\hline S. aureus & $\mathrm{R}$ & S & S & S & $R=8.0$ & - \\
\hline S. aureus & $\mathrm{R}$ & $\mathrm{R}$ & $\mathrm{R}$ & S & $\mathrm{R}=8.0$ & - \\
\hline
\end{tabular}

CFO = cefoxitin, OXA = oxacillin, PEN = penicillin G, AMC = amoxicillin with clavulanic acid, MIC CFO = microdilution in broth with cefoxitin, $\mathrm{R}=$ resistant, $\mathrm{S}=$ sensitive; Parameters according to CLSI 2018: $\mathrm{CFO}$ and $\mathrm{OXA}=\mathrm{S} \geq 22 / \mathrm{R} \leq 21, \mathrm{PEN}=\mathrm{S} \geq 29 / \mathrm{R} \leq 28, \mathrm{AMC}=\mathrm{S} \geq 28 / \mathrm{R} \leq 27, \mathrm{MIC}$ cefoxitin $=\mathrm{S} \leq 4 / \mathrm{R} \geq 8$. 
The low prevalence of $m e c A$ in beta-lactam resistant isolates reassert further molecular studies to detect the mechanisms involved in resistance.

Acknowledgements.- The authors thank "Conselho Nacional de Desenvolvimento Científico e Tecnológico" (CNPq) and "Coordenação de Aperfeiçoamento de Pessoal de Nível Superior" (CAPES) for financial support.

Conflict of interest statement.- The authors have no competing interests.

\section{REFERENCES}

Alatoom A.A., Cunningham S. A., Ihde S.M., Mandrekar J. \& Patel R. 2011. Comparison of direct colony method versus extraction method for identification of gram-positive cocci by use of Bruker Biotyper Matrix-Assisted Laser Desorption Ionization-Time of Flight Mass Spectrometry. J. Clin. Microbiol. 49(8):2868-2873. <https://dx.doi.org/10.1128/JCM.00506-11> $<$ PMid:21613431>

Almeida J.F, Aquino M.H.C., Magalhães H., Nascimento E.R., Pereira V.L.A., Ferreira T. \& Barreto M.L. 2013. Principais alterações no leite por agentes causadores de mastite no rebanho caprino dos estados de Minas Gerais e Rio de Janeiro. Arq. Inst. Biológico, São Paulo, 80(1):13-18. <https://dx.doi.org/10.1590/S1808-16572013000100003>

Bannoehr J. \& Guardabassi L. 2012. Staphylococcus pseudintermedius in the dog: taxonomy, diagnostics, ecology, epidemiology and pathogenicity. Vet. Dermatol. 23(4):253-e52.<https://dx.doi.org/10.1111/j.1365-3164.2012.01046.x> $<$ PMid:22515504>

Carbonnelle E., Mesquita C., Bille E., Day N., Dauphin B., Beretti J.L., Ferroni A., Gutmann L. \& Nassif X. 2011. MALDI-TOF mass spectrometry tools for bacterial identification in clinical microbiology laboratory. Clin. Biochem. 44(1):104-109. <https://dx.doi.org/10.1016/j.clinbiochem.2010.06.017> $<$ PMid:20620134>

Cauwelier B., Gordts B., Descheemaecker P. \& Van Landuyt H. 2004. Evaluation of a disk diffusion method with cefoxitin $(30 \mu \mathrm{g})$ for detection of methicillinresistant Staphylococcus aureus. Eur. J. Microbiol. Infect. Dis. 23(5):389-392. <https://dx.doi.org/10.1007/s10096-004-1130-8> <PMid:15112072>

Cavalcante M.P., Alzamora Filho F., Almeida M.G.Á.R., Silva N.S., Barros C.G.G. \& Silva M.C.A. 2013. Bactérias envolvidas nas mastites subclínicas cabra da região de salvador, Bahia. Arq. Inst. Biológico, São Paulo, 80(1):19-26. <https://dx.doi.org/10.1590/S1808-16572013000100004>

Cherkaoui A., Hibbs J. \& Emonet S. 2010. Comparison of two matrix assisted laser desorption ionization-time of flight mass spectrometry methods with conventional phenotypic identification for routine bacterial speciation. J. Clin. Microbiol. 48(4):1169-1175. <https://dx.doi.org/10.1128/JCM.01881-09> <PMid:20164271>

CLSI 2018. Performance Standards for Antimicrobial Disk and Diluition Susceptibility Tests for Bacteria Isolated from Animals; Approved Standards. 11th ed. Clinical and Laboratory Standards Institute, Wayne, PA.

Coimbra-e-Souza V., Rossi C.C., Jesus-de Freitas L.J., Brito M.A.V., Laport M.S. \& Giambiagi-de-Marval M. 2019. Diversity of species and transmission of antimicrobial resistance among Staphylococcus spp. isolated from goat milk. J. Dairy Sci. 102(6):5518-5524. <https://dx.doi.org/10.3168/ jds.2018-15723><PMid:30928272>

França C.A., Peixoto R.M., Cavalcante M.B., Melo N.F., Oliveira C.J.B., Veschi J.L.A., Mota R.A. \& Costa M.M. 2012. Antimicrobial resistance of Staphylococcus spp. from small ruminant mastitis in Brazil. Pesq. Vet. Bras. 32(8):747-753. <https://dx.doi.org/10.1590/S0100-736X2012000800012>

Garino Junior R.F., Camboim E.K.A., Das Neves P.B., De Sá A.V.V. \& Almeida A.P. 2011. Suscetibilidade a antimicrobianos e produção de betalactamase em amostras de Staphylococcus isolados de mastite caprina no semiárido paraibano. Arq. Inst. Biológico, São Paulo, 78(1):103-107.<https://dx.doi. org/10.1590/1808-1657v78p1032011>
Gomes F. \& Henriques M. 2016. Control of bovine mastitis: old and recent therapeutic approaches. Curr. Microbiol. 72(4):377-382. <https://dx.doi. org/10.1007/s00284-015-0958-8><PMid:26687332>

Gregory L., Lara M.C.C.S.H., Villalobos E.M.C., Hasegawa M.Y., Castro R.S., Rodrigues J.N.M., Araújo J., Keller L.W. \& Durigon E.L. 2009. Detecção do vírus da Artrite Encefalite Caprina em amostras de leite de cabras pela Reação em Cadeia da Polimerase (PCR) e Nested-PCR. ARS Vet. 25(3):142-146.

Jaffe R.I., Lane J.D., Albury S.V. \& Niemeyer D.M. 2000. Rapid extraction from and direct identification in clinical samples of methicillin-resistant staphylococci using the PCR. J. Clin. Microbiol. 38(9):3407-3412. <https://dx.doi.org/10.1128/JCM.38.9.3407-3412.2000><PMid:10970392>

Kuroda M., Ohta T., Uchiyama I., Baba T., Yuzawa H.I., Kobayashi L., Cui A., Oguchi K., Aoki Y. \& Nagai J. 2001. Plasmid-mediated resistance to vancomycin and teicoplanin in Enterococcus faecium. New Engl. J. Med. 319:157-161.

Langoni H., Domingues P.F. \& Baldini S. 2006. Mastite caprina: seus agentes e sensibilidade frente a antimicrobianos. Revta Bras. Ciênc. Vet. 13(1):51-54.

Oliveira D.C \& Lencastre H. 2002. Multiplex PCR strategy for rapid identification of structural types and variants of the mec element in Methicillin-Resistant Staphylococcus aureus. Antimicrob. Agents Chemother. 46(7):2155-2161. <https://dx.doi.org/10.1128/aac.46.7.2155-2161.2002><PMid:12069968>

Lima M.C., Souza M.C.C., Espeschit I.F., Maciel P.A.C.C., Sousa J.E., Moraes G.F., Ribeiro Filho J.D. \& Moreira M.S.A. 2018. Mastitis in dairy goats from the state of Minas Gerais, Brazil: profiles off arms, risk factors and characterization of bacteria. Pesq. Vet. Bras. 38(9):1742-1751. <https://dx.doi.org/10.1590/1678-5150-pvb-5698>

Lowy F.D. 2003. Antimicrobial resistance: The example of Staphylococcus aureus. J. Clin. Invest. 111(9):1265-1273. <https://dx.doi.org/10.1172/ JCI18535><PMid:12727914>

Ma X.X., Ito T., Tiensasitorn C., Jamklang M., Chongtrakool P., Boyle-Vavra S., Daum R.S. \& Hiramatsu K. 2002. Novel type of staphylococcal cassette chromosome mec identified in community-acquired methicillin resistant Staphylococcus aureus strains. Antimicrob. Agents Chemother. 46(4):1147-1152. <https://dx.doi.org/10.1128/aac.46.4.1147-1152.2002><PMid:11897611>

Martins K.B., Faccioli P.Y., Bonesso M.F., Fernandes S., Oliveira A.A., Dantas A., Zafalon L.F. \& Maria de Lourdes R.S.C. 2017. Characteristics of resistance and virulence factors in different species of coagulase-negative staphylococci isolated from milk of healthy sheep and animals with subclinical mastitis. J. Dairy Sci. 100(3):2184-2195. <https://dx.doi.org/10.3168/jds.2016-11583> $<$ PMid:28109594>

Melo D.A., Coelho I.S., Motta C.C., Rojas A.C.C.M., Dubenczuck F.C., Coelho S.M.O. \& Souza M.M.S. 2014. Impairments of mecA gene detection in bovine Staphylococcus spp. Braz. J. Microbiol. 45(3):1075-1082. <https://dx.doi. org/10.1590/s1517-83822014000300041><PMid:25477945>

Memmi G., Filipe S.R., Pinho M.G., Fu Z. \& Cheung A. 2008. Staphylococcus aureus PBP4 is essential for B-lactam resistance in in community - acquired methicillin resistant strains. Antimicrob. Agents Chemother. 52(11):39553966. <https://dx.doi.org/10.1128/AAC.00049-08><PMid:18725435>

Motta C.C., Rojas A.C.C.M., Dubenczuck F.C., Botelho L.A.B., Moreira B.M., Coelho S.M.O., Coelho I.S. \& Souza M.M.S. 2014. Verification of molecular characterization of coagulase positive Staphylococcus from bovine mastitis with matrix-assisted laser desorption ionization time offlight mass spectrometry (MALDI TOF MS) mass spectrometry. Afr. J. Microbial. Res. 8(48):3861-3866. <https://dx.doi.org/10.5897/AJMR2014.7071>

Murakami K.W., Minamide K., Wada W., Nakamura E., Teraoka H. \& Watanbe S. 1991. Identification of methicillin resistant strains of staphylococci by polymerase chain reaction. J. Clin. Microbiol. 29(10):2240-2244. <https://dx.doi.org/10.1128/JCM.29.10.2240-2244.1991><PMid:1939577>

Peixoto R.M., Mota R.A. \& Costa M.M. 2010. Mastite em pequenos ruminantes no Brasil. Pesq. Vet. Bras. 30(9):754-762. <https://dx.doi.org/10.1590/ S0100-736X2010000900008> 
Peixoto R.M., Peixoto R.M, Alves A.P.P., Peixoto L.J.S., Reges A.M. \& Costa M.M. 2013. Genes de resistência a antimicrobianos e produção de biofilme em Staphylococcus spp. isolados de caprinos leiteiros. Vet. Zootec. 20(2 Supl.1):343-344.

Rosato A.E., Kreiswirth B.N., Graig W.A., Eisner W., Climo M.W. \& Aecher G.L. 2003. mecA-blaZ corepressors in clinical Staphylococcus aureus isolates. Antimicrob. Agents Chemother. 47(4):1460-1463. <https://dx.doi. org/10.1128/aac.47.4.1460-1463.2003> <PMid:12654694>

Seng P., Rolain J.M., Fournier P.E., La Scola B., Drancourt M. \& Raoult D. 2010. MALDI-TOF-mass spectrometry applications in clinical microbiology. Future Microbiol. 5(11):1733-1754. <https://dx.doi.org/10.2217/fmb.10.127> <PMid:21133692>

Van Griethuysen A., Van Loo I., Van Belkum A., Vandenbroucke-Grauls C., Wannet W., Van Keulen P\& Kluytmans J. 2005. Loss of the mecA gene during storage of methicillin-resistant Staphylococus aureus strains. J. Clin. Microbiol. 43(3):1361-1365.<https://dx.doi.org/10.1128/JCM.43.3.13611365.2005><PMid:15750108>

Weller T.M.A. 2000. The distribuition of $m e c A, m e c R I$ and $m e c I$ and sequence analysis of mecI and the mec promoter region in staphylococci expressing resistance to methicillin. J. Antimicrob. Chemother. 43(1):15-22. <https:// dx.doi.org/10.1093/jac/43.1.15>

Zhang K., Sparling J., Chow B.L., Elsayed S., Hussain Z., Church D.L., Gregson D.B., Louie T. \& Conly J.M. 2004. New quadriplex PCR assay for detection of methicillin and mupirocin resistance and simultaneous discrimination of Staphylococcus aureus from coagulase-negative staphylococci. J. Clin. Microbiol. 42(11):4947-4955. <https://dx.doi.org/10.1128/JCM.42.11.49474955.2004><PMid:15528678> 